九州大学学術情報リポジトリ

Kyushu University Institutional Repository

Revisional Notes On Camponotus Herculeanus

Linne And Close Relatives In Palearctic Regions (Hymenoptera : Formicidae)

Yasumatsu, Keizo

Entomological Laboratory, Department of Agriculture, Kyushu University

Brown Jr, William Louis

Harvard University

https://doi.org/10.5109/22643

出版情報：九州大学大学院農学研究院紀要. 10 (1)，pp.29-44，1951-10. Kyushu University バージョン：

権利関係 : 
Journal of the Faculty of Agriculture, Kyūshū University, Vol. 10, No. 1

October 30, 1951

\section{REVISIONAL NOTES ON CAMPONOTUS HERCULEANUS LINNÉ AND CLOSE RELATIVES IN PALEARCTIC REGIONS ( HYMENOPTERA : FORMICIDAE)}

Keizô Yasumatsu and William L. Brown, Jr.

The familiar black and red-and-black carpenter ants related to Camponotus herculeanus Linné form an essentially Holarctic group of a few species and subspecies bearing a great superfluity of names. For convenience only, the group may be divided geographically into Eurasian and North American, sections. The North American forms have recently been treated fully by Creighton (1950), and his work is accepted with two alterations (Brown, 1950).

Relatively little synonymy applies among European forms, although the identity of Linne's original $C$. herculeanus may be questioned. The chief problem here is the separation of the "accepted" herculeanus from the closely related ligniperda (Latreille); certainly the two species have been confused by many European myrmecographers. Menozzi (1922) has attempted to put their separation on a more definite basis by claiming differences in the male genitalia in addition to the more commonly accepted criteria of color. and sculpture in the female and worker castes. Our examination of the genitalia in a few specimens of each form has failed to show significant genitalic differences, but more material would perhaps be more revelatory of characters. It seems probable that ligniperda exists as a separate specific entity, however, though its ethological, distributional and even morphological features are in need of clarification by some specialist with a broad field knowledge of both common forms.

Emery has rightly eliminated Forel's variety herculeano-ligniperda as representing the small, dark minim worker of the "typical" 
ligniperda. Menozzi's variety nadigi (1922) is an almost completely black form of herculeanus such as is found at many other points in the range of the latter. The present evidence does not support its treatment as a geographical race, and we provisionally consider it a synonym. The European fauna is considered to consist of $C$. herculeanus, $C$. ligniperda and $C$, vagus Scopoli. The lastnamed is quite distinct as a species, and need not be mentioned further here.

The Asian fauna of the group has been dealt with successively and almost completely intra-nationally by western European, Russian, American and Japanese specialists. It is scarcely surprising that there exist one or more each European, Russian, American and Japanese names for most forms which have been considered distinct even in the past. The terrible taxonomic tangle resulting from this nomenclatorial short-sightedness should serve as a warning to taxonomists who refuse to study variation beyond the nearest political boundaries. It is the chief purpose of the present paper to analyze the Asian members of the group on the basis of modern population systematics and to unravel the nomenclatorial tangle as far as possible. The pertinent literature is so widely scattered and voluminous that it is almost certain we have overlooked many references, especially in the more recent European and Russian journals. While many of these may contain valuable distributional or ethological data, the probability of misidentifications occurring in them is strong enough to render their uncritical acceptance only a further source of confusion.

In ordér that the reader may follow our discussion more easily, we here present our systematic conclusions regarding the Eurasian fauna in skeleton arrangement:

Camponotus herculeanus herculeanus (Linné)

= var. nadigi Menozzi (new syn.)

= var. montana Ruzsky (Emery syn.)

= var. whymp ri Forel (Creighton syn.)

=var. jacutica Karawajew (new syn.)

Camponotus herculeanus japonicus Mayr

(a) Absolute synonyms

= var. miltotus Wheeler (new syn.)

=subsp. wui Wheeler (new syn.) 
(b) Concolorous or nearly concolorous black forms referable mainly to japonicus, but with clypeus and pubescence variably tending toward those of $C$. $h$. herculeanus. Intergrades, japonicus $\times$ herculeanus.

= var. aterrima Emery (new syn.)

$=$ var. sachalinensis Forel (new syn.)

$=$ var. saxatilis Ruzsky (new syn.)

= var. manczshurica Ruzsky (new syn.)

=var. sanguinea Karawajew (new syn.)

(c) Forms with pubescence of japonicus, clypeus intermediate, head and gaster black, alitrunk red. Intergrades, japonicus $\times$ herculeanus.

$=$ var. crientat $a$ Karawajew (nom. praeocc.)

- var. atrox Emery, nom. pro. cruentata (new syn.)

= var. koreanus Teranishi (new syn.)

=var. jeholensis Teranishi (new syn.)

Camponotus ligniperda (Latreille)

$=$ var. herculeano-ligniperdia Forel (Emery syn.)

Camponotus obscuripes obscuripes Mayr

Camponotus obscuripes hemichlaena Yasumatsu et Brown, subsp. nov.

Camponotus yessensis Teranishi (raised to species)

-Camponotus formosensis Wheeler (raised to species)

Camponotus vagus Scopoli (confirmed as a good species)

Species inquirendae

Camponotus punctatissimus Emery

Camponotus cilicicus Emery.

Camponotus vagus var. kodorica Forel . .

Camponotus herculeanus eudokiae Ruzsky

The Relationship of Camponotus herculeanus to C. japonicus

The chief characters of taxonomic value in the herculeanus complex are pilosity and color; density and opacity of gastric sculpture and the slightly advanced clypeal lobe of japonicus are of importance also. C. ligniperda has the most shining gastric surface, with very light cross-striation, and usually has the entire alitrunk as well as a considerable portion of the first gastric segment red. Its gastric pubescence falls far short of reaching the 
posterior borders of the segments in the middle. C. herculeanus has somewhat stronger gastric sculpture; the body is most often black except for the legs and a small area containing the posterior propodeum, node and sometimes the extreme base of the gaster, which are deep red; the gastric pubescence usually reaches nearly to the posterior borders of the gastric segments in the middle and only rarely slightly surpasses them (the latter is probably and intergradient condition). C. japonicus has quite the heaviest gastric sculpture, and this produces a silky opacity of the surface; the body and legs are typically concolorous black; the gastric pubescence is yellowish, coarse and dense, surpassing the posterior borders of the segments often by half or more of its length. Ligniperda will not concern us further here.

"In dealing with color, it must be emphasized that the complex varies considerably according to ecological as well as genetic factors. This is especially true of herculeanus and japonicus. $C$. herculeanus herculeanus normally, nests in timber in cold boreal or subalpine regions. Near timberline on Mt. Washington, in the northeastern United States, the only trees (Picea) are strongly dwarfed and not suitable for nesting, and herculeanus is forced to nest in the thin soil beneath rocks under extremely cold, arid and exposed conditions. Nests taken by Brown in this locality are all "depauperate" in that the workers are all smaller and much lighter in color than in "normal" nests from lower altitudes on the same mountain. The timberline workers have the alitrunk a faded red throughout.

A somewhat similar phenomenon may be noted in japonicus. Specimens from arid regions in North China often have large parts of the head dark red (var. miltotus Wheeler). Brown has taken workers, usually majors, of this type in Shensi running in the same files with "normal" black specimens. Where cold ard aridity reach extremes together, as in the high mountains of Sikang, both D. C. Graham and Brown found nests with all or most of the workers having almost the entire head and alitrunk a pale reddish color. It is therefore evident that color variants in this group must be treated with the utmost caution.

In Asia, herculeanus is most typically associated with the boreal and alpine coniferous forests of the Siberian taiga and the highest mountains of China, Japan, trans-Himalaya, etc. 
Japonicus is typically a soil nester in the more temperate plains and lower mountains of China and Japan. The ranges of the two reach toward each other and are deeply interlocked in the mountain chains so abundant in eastern Asia. The present evidence shows, we believe, that the two forms can and do intergrade in most or all intermediate zones, although the transition appears fairly sharp in mountainous regions. This sharp transition is probably due in large part to the activity of man in lumbering and clearing the middle mountain slopes for agriculture, a practice followed widely in China and Japan. The relatively undisturbed regions are remote, but would repay study.

Intergradation of a much more gradual sort is fairly clear in a review of low-altitude material ranging from south to north in East Asia. The slightly projecting clypeal border and dense long pubescence which characterize japonicus become less and less marked as one goes northward in China and Manchuria, producing the forms known as aterrima, achalinensis, saxatilis (Ural Mts.), manczshurica and sanguinea, which seem to grade insensibly into herculeanus. This intergradation occurs over a wide belt stretching from the southern Urals to Sakhalin. Unfortunately, we have little or no information concerning the state of affairs in wide stretches of Central Asia: Sinkiang, Chinghai, Mongolia; if our interpretation is correct, intergrades should occur in these regions on the isolated mountain ranges.

The forms called atrox, jeholensis and koreanus are approximately equivalent and are essentially japonicus in sculpture and pilosity, while the alitrunk is a rather uniform red, a color type commonly encountered among herculeanus populations (see above). This form has been reported (in the original descriptions) from mountains in northern Korea and Manchuria, and Yasumatsu has taken specimens in the mountains of Shansi.

The forms discussed in the two foregoing paragraphs are considered by us to represent the array of phenotypes expected of a hybrid swarm formed at the meeting of two geographical races which have been or less completely separated, possibly during the relatively mild glaciation undergone by East Asia. This swarm appears to follow conditions mentioned in Ernst Mayr's "Evolution and the Origin of Species" (1942). It is interesting to note that japonicus specimens with slightly thinned gastric 
pubescence from Boketu and White River, Barum, Manchuria (P. and $\mathrm{H}$. Dorsett) in the Museum of Comparative Zoology, which were determined as "aterrima" by Wheeler, are accompanied by a collector's note stating that they were taken from the bases of willow trees. Does this indicate an intergradation in nesting habits, as might be expected to occur?

Carrying the data to their logical conclusion, we here treat japonicus as a southern geographical race of herculeanus in spite of the fact that the great majority of specimens we have seen are definitely assignable to one or the other name. We place the intergrades in the synonymy of japonicus because most of them seem closer to the southern race, but some of them could equally well be placed under the "typical" herculeanus. Illustrative of the confusion is an extract of a letter from the late Dr. Karawajew to Teranishi, both of whom worked extensively in the complex:

". . . jacutica is a synonym of sachalinensis; aterrima Teranishi (Zool. Mag., 41 : 240)=saxatilis ; aterrima Karawajew (Rev. Russ. d'Ent., 12: 594, 1912)=jacutica."

The form jacutica, of course, is the "typical" herculeanus, which in Asia has gone under the names whymperi and montana as well. Specimens of herculeanus with "typical" pilosity and sculpture, but entirely black; are known from the highest Japanese mountains, and we have seen similar specimens from near the top of the small island Uotsurijima (= Hoa Pin San) at about 1200 feet altitude. This island is only a short distance off the northern end of Formosa. The specimens were furnished by the collector, the late Mr. Masaki; they probably represent an isolated colony originated by a wind-borne female. It is an interesting corollary of this arrangement that herculeanus seems to produce extreme melanic forms in the southern montane extensions of its range on all continents; only in North America does the melanic population seem to show the characteristics of a reasonably well-defined geographical race in $C$. herculeanus modoc Wheeler. Further, more intensive studies of this group in such montane regions may show that the situation is much more complex than our arrangement admits at present. We have gone as far here as purely morphological and distributional data will permit, and we believe that future students will have to resort to interbreeding and trans- 
plantation experiments in order further to clarify the relationships between the populations.

\section{Camponotus herculeanus herculeanus (Linné)}

Formica herculeana Linné, 1758, Syst. Nat., edition 10, 1: 579.

Camponotus herculeanus Emery, 1925, Gen. Ins., Fasc. 183, pp. 72 73 . See for further synonymy and older references.

Camponotus herculeanus pennsylvanicus var. whymperi Forel, 1902, Trans. Ent. Soc. London, p. 669, 9 \&, original description from N. American specimens. Emery, 1925, loc. cit., synonymy. Forel, 1903, Ann. Mus. Zool. Acad. Imp. Sci. St. Petersbourg, 8: 14, Siberie de sud-ouest. Kisselewa, 1925, Rer. Tomsker Staats-Univ., 75: 73, Ussuri. Ruzsky, 1936, Trav. Inst. Sci. Biol. Tomsk, 2: 89-90, Transbaikal. gebiet.

Camponotus herculeanus Kisselewa, 1925, Ber, Tomsker Staats-Univ., 75: 75, Ussuri. Ruzsky, 1936, Trav. Inst. Sci. Biol. Tomsk, 2: 89, Transbaikalgebiet. Creighton, 1950, Bull. Mus. Comp. Zool., Harvard Univ., 104: pp. 363 370, discussion of C. herculeanus group in N. America and synonymization of var. whymperi. See also European records and other intormation in numerous faunal lists and other papers by European and Russian writers, esp. Kuznezov-Ugamsky, Karawajew, Holgersen, et al. For biology, see Eidmann, esp. 1928, Zeitschr. f. angewandte Fint., pp. 229-253, 9 figs.

Camponotus herculeanus var. jakutica Karawajew, 1929, Mem. Classe Sci. Phys. Math. Acad. Sci. Ukraine, 8: 210, original description, Yakutsk. 1931, Zool. Anz., 93: 30, Yakutsk, Ussuri, Irkutsk, Umgebung des Baikalsees, Sakhalin. 1931, Ibid., 94: 107. Irkutsk, Sakhalin, Yakutsk, (new synonymy).

Camponotus herculeanus herculeanus Kôno et Sugihara, 1939, Trans. Kansai Ent. Soc., 8: 10, Sakhalin, northeastern Hokkaido. (For additional partim synonymy see references under var. sachalinensis given in the synonymy of $\mathrm{C}$. herculeanus japonicus below. Probably most sachalinensis records are based on the black, neartypical form of herculeanus, but so long as these forms are considered intergradient between the two races it matters little under which name they are placed in synonymy.).

Distribution: $C$. herculeanus herculeanus has a Holarctic range surpassed by few other ants. It is found almost everywhere within the natural ranges of the coniferous genera Picea and Abies, particularly the former, the presence of which seems almost to be a prerequisite to the development of the ant in its most typical form. This attachment is more or less exclusive, for other species of Camponotus are rare or absent in the various muskegs, taiga and montane forests of the spruce belt. The fact that spruce and spruce-fir forests are usually relatively discontinuous may provide one reason for the seeming scarcity of intergrades between "typical" herculeamus and japonicus in mountain areas in Japan and China south of Manchuria. This statemen of ecological 
preference is based on rather scanty data and on inferences drawn from locality reports, as well as from limited observations by the junior author in North America. It is unfortunate that the great majority of published records contain little or no ecological data.

\section{Camponotus herculeanus japonicus Mayr}

Camponotus japonicus Mayr, 1866, Verh. 7ool.-bot. Ges. Wien, 16: 885, 9, original description, Japan.

Camponotus japonicus Emery, 1925, Gen. Ins., Fasc. 183, pp. 72-73, further references.

\section{(a) absolute synonyms}

Camponotus japonicus var. miltotus Wheeler, 1929, Amer. Mus. Novit., No. 361, p. 9, 9 major, (new synonymy).

Camponotus japonicus subsp. wui Wheeler, 1929, Ibid., p. 9, 9 media, (new synonymy).

\section{(b) Black intergrades to herculeanus}

Camponotus japonicus var. aterrima Emery, 1894, Ann. Mus. Stor. Nat. Genova, 34: 478, nota, 9 , original description as $C$. pennsylvanicus var. (new synonymy). Emery, 1925, Gen. Ins., Fasc. 183, p. 73, further references. Karawajew, 1913, Rev. Russe d'Ent., 12: 592, part.? Amur, Korea, Sakhalin. 1927, Trav. Mus. Zool. Acad. Sci. Ukraine, 2: 344, Ussuri, Irkutsk. Mocsáry, 1901, Dritte Asia. Forschungsreise Gr. E. Zichy, 2: 132, "China": Daba, Kalgan, Tshan-pin-cho. Baltz, 1915, Rev. Russe d'Ent., 25: 318, observation. Kisselewa, 1925, Ber. Tomsker Staats-Univ., 75: 73, Ussuri. Santschi, 1925, Bull. Soc. Vaud. Sci. Nat., 56: 88, Quelpart I. Wheeler, 1931, Peking Nat. Hist. Bull., 5: 75, summary of records from China, incl. records published by Gee and by Wheeler 1919-1929. Ruzsky, 1915, Ann. Mus. Zool. Acad. Sci. Petersbourg, 19: 479, Tibet. 1936, Trav. Inst. Sci. Biol. Tomsk, 2: 90, Transbaikalgebiet. Teranishi, 1929, Zool. Mag., Tokyo, 41: 240, E. Siberia, China, Korea, Sakhalin, Hokkaido. 1936, Insects of Jehol, VII. Formicidae, pp. 3, 10, fig., Jehol. 1940, Posthumous section in Teranishi Memorial Volume, p. 72, southern Sakhalin, central Hokkaido. Sjöstedt, 1935 , Arkiv f. Zool., $28 \mathrm{~A}: 5$, Kamchatka [?].

Camponotus herculeanus var. sachalinensis Forel, 1904, Ann. Mus. Zool. Acad. Sci. Petersbourg, 8: 281, original description, Sakhalin, Mongolia, Manchuria, (new synonymy). Emery, 1925, Gen. Ins., Fasc. 183, p. 73, further references. [often referred to C. h. pennsylvanicus as a var.] Yano, 1910, Zool. Mag., Tokyo, 22: 422, Sakhalin, Siberia. Karawajew, 1913, Rev. Russe d'Ent., 12: 592, Baikal, Manchuria. 1927; Trav. Mus. Zool. Acad. Sci. Ukraine, 2: 344, Ussuri. Teranishi, 1932, Trans. Kansai Ent. Soc., 3: 50, Sakhalin, Shinshu district of Honshu. 2000-2300 M. alt. Uchida, 1936, Biogeographica, Tokyo, 1: 72, Mt. Daisetsu in central Hokkaido; rarer than saxatilis. Morishita, 1945, Nippon Seibutsushi, 5: Insecta, 2: 17, 21-23, 27, distribution in central mountainous regions of Japan; lower limit of vertical distribution : $1300 \mathrm{M}$. 
Camponotus herculcanus saxatilis Ruzsky, 1895, Trav. Soc. Nat. Univ. Kasan, 28 (5): 7, original description, all castes. (new synonymy) Emery, 1925, Gen. Ins., Fasc. 183 , p. 73, as var. of C. h. pennsylvanicus, further references, southern Ural Mts. to Volga $\mathrm{R}$.

Camponotus japonicus var. manczshurica Ruzsky, 1915, Ann. Mus. Zool. Acad. Sci. Petrograd, 19: 481, 9 , Manchuria, (new synonymy).

Camponotus japonicus var. sanguinea Karawajew, 1929, Mem. Acad. Sci. Ukraine, 13: 212 , all female castes, (new synonymy).

\section{(c) Intergrades to herculeanus with red alitrunk}

Camponotus herculeanus Japonicus var. cruentata Karawajew, 1912, Rev. Russe d'Ent., 12: 595, Q, nec Latreille; original description, Tshinjasi-san, N. Korea, (preoccupied).

Camponotus japonicus var. atrox Emery, 1925, Gen. Ins., Fasc. 183, p. 73, pro cruentata Karawajew, nec Latreille, (new synonymy).

Camponotus herculeanus japonicus var. cruentata Teranishi, 1929, Zool. Mag., Tokyo, 41: 241, N. Korea, Mt. Kongo in central Korea.

Camponotus (C.) herculeanus jeholensis Teranishi, 1936, Insects of Jehol, VIl. Formicidae, pp. 4, 10, fig., Jehol, (new synonymy).

Camponotus (C.) herculeanus [sic] var. koreanus Teranishi, 1940, Posthumous section in Teranishi Memorial Volume, p. 71, Mt. Kongo in central Korea, (new synonymy).

Examples from the southern Urals (saxatilis) and many from North China, Manchuria, etc. are so similar to the "typical" japonicus from Japan that they cannot really be separated, so that saxatilis and aterrima might be considered as intergrades or as absolute synonyms with equal justice. The description of sanguinea was published in the same year as that of miltotus, and Karawajew obviously had a form agreeing closely with Wheeler's type in the Museum of Comparative Zoology. The form Wheeler called wui clearly belongs to japonicus; the yellowish borders and other features of the gaster are found in all japonicus if examined closely, especially crushed specimens. We have not seen manczshurica, but the description answers well to intergradient specimens from Manchuria. If future study were to show that japonica is really a distinct species, all the above forms would probably still have to be considered synonymous with it. Sachalinensis, as already mentioned, seems truly intergradient, and most of the specimens on which the literature is based could be put under herculeanus herculeanus more easily than under japonicus.

The forms atrox (cruentata), koreanus, and jeholensis appear to be equivalent. It is doubtful that the name koreanus would have seen print had Teranichi lived longer. This color variant of japonicus is widely but discontinuously distributed in the 
mountains of Korea, Manchuria and North China; Yasumatsu has taken it in the mountains of Shansi. If japonicus is ever returned to specific status, "atrox" may well have to be considered as an alpine subspecies.

The subspecies japonicus is probably the most conspicuous and familiar of all ants throughout the plains and lower hill regions of China and much of Japan. Emery has recorded it from upper Burma. Brown has seen specimens from D. C. Graham and has collected specimens himself from western China at altitudes up to nearly 2500 meters in the mountains along the Szechuan-Sikang (Chinese Tibet) border; in Shensi, japonicus was plentiful at 2100 meters in the Tsin Ling Shan at Miao T'ai Tze. The nests are built in the soil, commonly along the dikes between the rice-paddies, and are often furnished with a disorderly crater of coarse earth particles. The nest entrance may be up to a centimeter in diameter. The southern limits of the distribution are unknown, but since the ant is common at Kunming, it must extend down the mountains of Burma and Indo-China for sorne distance. It has nut been taken by any of the recent collectors in Formosa or Okinawa, nor is it known just how nearly continuous the range across to the Volga is from Mongolia. The similarity to Camponotus pennsylvanicus of the eastern half of North American is particularly striking.

While we are forced by the available data to consider japonicus as most likely a subspecies of herculeanus, we so assign it with great reluctance and some uneasiness, and we by no means consider the question completely closed. We believe, however, that the subsidiary synonymy suggested above is for the most part firmly founded. The removal of these doubtful names from the taxonomic field is necessary to the development of the knowledge of the group and is long overdue.

\section{Camponotus obscuripes obscuripes Mayr}

Camponotus ligniperdus var. obscuripes Mayr, 1871, Verh. Zool.-bot. Ges. Wien, 28: 645 , 9 , original description.

Camponotus ligniperdus (nec Latreille) F. Smith, 1874, Trans. Ent. Soc. London, p. 402, Japan: specimens were from Hiogo. Matsumura, 1911, 1930, 1931, 1932, in various editions and modifications of Illustr. Ins. Japan, with figures, partim. Of localities cited, obscuripes does not occur in Kyushu, Korea, China or Europe.

Camponotus ligniperdus var. obscuripes Forel, 1901, Mitt. Naturh. Mus., Hamburg, 18:

70, Yesso [now called Hokkaido]. Anclré, 1903, Bull. Mus. Hist. Nat. Paris, 
p. 128, Tokyo. Matsumura, 1911, Jour. Coll. Agr., Tohoku Imp. Univ., 4: 99, southern Sakhalin.

Camponotus herculeanus obscuripes Emery, 1908, Deutsche Ent. Zeitschr., p. 185, ९. Watanabe, 1935, Fauna of Towada and Hakkoda Districts, p. 44, Mt. Hakkoda and Tsuta, Honshu. 1937, Cat. Injur. For. Ins. Japan, p. 4, injuring timber. Yasumatsu, 1938, Ins. Japon. Illustr. Icon. Color. Nat. depicta, p. 350, pl. 157, fig. 614, 9 , partim, short description, Sakhalin to Shikoku, Kyushu incorrect. Konô et Sugihara, 1939, Trans. Kansai Ent. Soc., 8: 9, Hokkaido.

Camponotus (s. str.) ligniperda var. obscuripes Yasumatsu, 1940, Mushi, 13: 1, Tsushima. Camponotus ligniperdus obscuripes Forel, 1907, Mitt. Natur. Mus. Hamburg, 24: 19, Gefu, recte Gifu.

Camponotus herculeanus var. obscuripes Masaki, 1937, Kontyû, 11: 84, Hachijo I. Yuki, 1938, Hiroshima Konchu Dokokaishi, 4: 12, Itsukushima. Nakano, 1938, Kansai Konchu Zasshi, 5: 83, Sakhalin.

Camponotus herculeanus ligniperda var. obscuripes (some references with slight variations in spelling) Yano, 1910, Zool. Mag., Tokyo, 22: 422, partim, Hokkaido and Honshu only. Wheeler, 1928, Boll. Lab. Zool. Portici, 21: 117, 127, partim, Honshu only. Teranishi, 1929, Zool. Mag., Tokyo, 41: 239-240, partim, Hokkaido, Honshu, Shikoku only; alates captured: 6/iv Kyoto, 7/v Mt. Chikuba, 30/v Gumma Prefecture, 8/vii Kamikochi, 25/v Sapporo; nests at roots of pines. Imanishi, 1930, Kontyâ, 4: 186, Mt. Tateyama, Honshu. Teranishi, 1931, Trans. Kansai Ent. Soc., 2: 28, Shikotan, Kurile Is. 1940, Teranishi, in Posthumous Section of Teranishi Memo. rial Volume, p. 71, partim, Hondo and Shikoku, non Kyushu, Korea or Saishu I. Sugihara, 1933, Kansai Konchu Zasshi, 1: 79, Shikoku, alt. 800-1600 M. Baba, 1935, Mushi, 8: 25, Sado I. Baba, 1946, Mag. Ins. Ecology, 1: 27, Musashi Prov. 1947, lbid., 2: 18, fig., ९, Mt. Ontake, Honshu, struggle with C. kiusiuensis Santschi. Yoshioka, 1939, Trans. Kansai Ent. Soc., 8: 67, Kiryu, Gumma Prefecture, Honshu. Morishita, 1945, Mushi, 13: 22, 25, southern Hokkaido, northern Honshu. Azuma, 1938, Ent. World, 6; 242, Minoo, Honshu. 1950, Ent Rev. Japan, 5: 47 48, Pl. 1, fig. 3, + , further references.

In the synonymy above, we have tried to give a complete summary of references, particularly those appearing in Japanese journals. The reader should note that all previous records from Kyushu and extreme southwestern Honshu belong to the subspecies hemichlaena nov. The typical obscuripes ranges from the mountains of Shikoku north to southern Sakhalin and the southern Kuriles; in the west, its range extends to Tsushima in the Strait. The Korean record refers to the form "alrox" of japonicus, and records of ligniperdus or obscuripes from Quelpart Island are probably erroneous also.

In color, obscuripes usually differs in that the red of the alitrunk and gastric base is lighter and more yellowish than in European ligniperda; however, some Japanese specimens are equally dark. Many Japanese specimens show very feeble bluish 
metallic reflections on the integument, not seen in the European ligniperda. The sculpture and pubescence of the gaster are very similar in the two species, and the prime difference still used is the blackish color of the legs in obscuripes. While this is a relatively minor difference, we believe that distributional characteristics force the specific recognition of the Japanese form. Apparently, the true ligniperda does not occur in East Asia; at least, it has not been reported in the literature available to us. It is surprising that neither form seems to occur in China or Korea, but our study certainly indicates that this is the case.

Camponotus obscuripes hemichlaena subspecies nov.

This subspecies has been included in many former reports of obscuripes. For partim synonymy, refer to $C$. obscuripes obscuripes; all previous records from Kyushu and probably some from Honshu refer to hemichlaena. Investigation during $1950^{\circ}$ indicates that very rarely the typical obscuripes occurs in the mountains of Kyushu (Shiiba and Mt. Unzen). We have not yet found obscuripes obscuripes individuals in hemichlaena nests, or vice versa. The Kyushu populations of typical obscuripes may either represent alpine intrusions from the north, or else may be relicts of an original and uniformly typical obscuripes population dating from glacial times. The situation with regard to intergrades not being clear as yet, it is impossible to determine with complete finality whether hemichlaena is a good species, a geographical race, or possibly even a mere ecotype. Since we have scant reason to consider the black prothorax as other than a well fixed genetic character, and taking into account the distributional evidence, we feel that hemichlaena is best considered a subspecies for the present. For a good figure of the new subspecies, see the reference of Yano, 1932, in Icon. Ins. Japan, Hokuryukan, p. 328; localities cited are incorrect except for Kyushu and possibly southern Honshu; as $C$. herculeanus var. obscuripes.

Worker (Holotype and paratypes): With the characters of typical obscuripes, and varying similarly in depth of the red of alitrunk and gastric base. The only difference noted is that hemichlaena has the entire prothorax black, whereas in the typical form, the prothorax is concolorous with the rest of the alitrunk or only slightly darker. Color best seen in alcohol. 
Holotype [Entomological Laboratory, Kyushu University] 13. ix. 1939, Hikosan, Prov. Buzen, Kyushû, K. Yasumatsu leg.

124 Paratypes: [Museum of Comparative Zoology; U. S. National Museum; Entomological Laboratory, Kyushû University] see under distribution below.

Distribution: Kyushu and extreme southwestern Honshu, where it almost completely replaces obscuripes obscuripes. No intergrades between the two subspecies have yet been found, but they should occur in the junction zone in southern Honshu.

Localities: Honshu-Tsudamura, Prov. Aki; Gokurakujiyama, Prov. Aki ; Taishakukyo, Prov. Aki. Kyushu-Sobosan, Prov. Bungo; Ichibusayama, Prov. Higo; Handa-plateau, Prov. Bungo; Kirishimayama, Prov. Osumi; Taradake, Prov. Hizen; Kuboteyama, Prov. Buzen; Inugatake, Prov. Buzen; Hikosan, Prov. Buzen; Inunakiyama, Prov. Chikuzen; Wakasugiyama, Prov. Chikuzen; Homansan, Prov. Chikuzen; Yakushima Island.

The nests are normally built in logs and stumps of conifers, especially pine and cryptomeria, in rather shady places. Sometime $\mathrm{S}$ the nests are made in the timbers of old buildings. Yasumatsu observed injury to timbers at the Hikosan Meteorological Observatory in 1937.

\section{Camponotus yessensis Teranishi (Change of status)}

Camponotus helcureanus [sic] vagus var. yessensis Teranishi, 1940, in Posthumous. Section of Teranishi Memorial Volume, p. 72, $\$$, original description, Hokkaido. Camponotus herculeanus vagus var. yessensis Morishita, 1941, Mushi, 13: 93; records from Honshu: Mt. Yakushidake, 400 M.; Mt. Hayachine, 550 M.; Kadoiri, Minoo District, 400 M.; Sugo, Yamashiro Prov., 360 M. Yasumatsu, 1941, Mushi, 13: 96; record from Kyushu: Hikosan, 700-800 M.

This species is quite certainly a distinct species not very closely related to any other Japanese Camponotus; it is only superficially similar to $C$. vagus from southern Europe. The closest relationship is with $C$. laevigatus $\mathrm{F}$. Smith from western North America, but yessensis is distinct from this species by pilosity and sculptural characters. Teranishi's species has very abundant fine, dense, erect pilosity over the entire dorsum of head and body and on antennal scapes and legs. True pubescence is nearly or quite absent from the gastric dorsum. The entire insect is black, nearly smooth and distinctly shining. Apparently it is widely distributed in the mountains of Japan at moderate eleva- 
tions. The nests are built in rather dry logs and stumps, probably in situations similar to those in which laevigatus occurs in America.

\section{Camponotus formosensis Wheeler (Change of status)}

Camponotus maculatus taylori var. formosae Wheeler, 1909, Bull. Amer. Mus. Nat. Hist., 26: 336, worker, original description, Formosa. Yano, 1910, Zool. Mag., Tokyo, 22: 422, Formosa.

Camponotus herculeanus r. punctatissimus Forel (?), 1913, Arch. Natur., 79: 200, worker, Formosa.

Camponotus barbatus albosparsa var. formosae Emery, 1929, Gen. Ins., 183: 93, Formosa.

Camponotus punctatissimus formosensis Wheeler, 1929, Bol. Lab. Zool. gen. agr., Portici, 24: 62, Taihoku. Sonan, 1939, Memorial Volume, 30 Years Anniversary of the Taiwan Gov. Mus., p. 212, Formosa.

Camponotus barbatus taylori var. formosae Teranishi, 1940, in Posthumous Section of Teranishi Memorial Volume, p. 60, Formosa.

A review of the types in the Museum of Comparative Zoology, Harvard University of this form and of additional specimens, all from Formosa, lead to doubts that formosensis can rightly be considered a race of Emery's enigmatic species punctatissimus (see under species inquirendae). There are no specimens referred to punctatissimus in any of the parts of Wheeler's original collection, and it is extremely doubtful that Wheeler. knew any more about Emery's form than appeared in the punctatissimus description. If this is correct, we can see little correspondence between the Formosan specimens and the punctatissimus description. Emery mentions no unusual pilosity features; which he surely would have done had he been confronted with Wheeler's types.

Formosensis has very abundant coarse, yellowish-white erect pilosity on the dorsal surfaces of head and body, and the pubescence is remarkably long and dense, especially conspicuous and forming a closely appressed and slightly waved, anteriorly directed vestiture on the anterior dorsum of the alitrunk. The color is black and the sculpture coarse and opaque. This form appears to represent an extreme development of the tendencies shown by japonicus, but formosensis is so aberrant that we are forced to consider it a distinct species.

Forel had previously (reference not available) recorded a "punctatissimus" from Formosa, though we do not know the basis of his identification and consider it doubtful. Interesting enough, 
Emery later (1925) raised punctatissimus to specific status, though he did not recharacterize it. The original description would lead one to believe that punctatissimus was very close, if not identical with japonicus. Until Emery's species has been better described and compared with close relatives, both it and formosensis must remain in some doubt. Meanwhile, we propose to consider formosensis a distinct species for practical reasons.

\section{Species inquirendae}

Camponotus punctatissimus Emery

Camponotus pennsylvanicus var. punctatissimus Fmery, 1894, Ann.

Mus. Stor. Nat. Genova, 34: 477, 9 , Burma.

Camponotus punctatissimus Emery, 1925, Gen. In., Fasc. 183, p. 74, Burma, Tonkin, Formosa [?].

The discussion, see under $C$. formosensis above.

Camponotus cilicicus Emery, 1908, Deutsche Ent. Zeitschr., p. 186.

This species was briefly described by Emery, and we know nothing concerning it. Taurus was given as the original locality. Camponotus vagus var. kodorica Forel, 1913, Ann. Soc. Ent. Belg., 57: 145, Caucasus.

Camponotus herculeanus eudokiae Ruzsky, 1936, Trav. Inst. Sci. Biol. Tomsk, 2: 90, Transbaikalgebiet.

We know this form only through the original reference, which both of us have not seen. If this species really belongs to the herculeanus complex, it is very probably just another addition to Ruzsky's already extensive synonymy in this group.

In the preparation of this paper, we owe a debt of gratitude to Dr. M. R. Smith of the U. S. National Museum for loaning the extensive collections of Camponotus made by D. C. Graham in West China and to Dr. J. C. Bequaert for facilitating examination of specimens in the Wheeler Collection. We wish to tender our grateful thanks to Prof. T. Esaki, of the Kyushu University, for the privilage of studying Camponotus-specimens in the collection of the University. We are also indebted, for the gift of specimens, to Messrs. K. Shibuya, R. Morimoto, S. Miyamoto, T. Miyake, S. Otsuka, Prof. M. Chujo, H. Okamoto, T. Ichiba, and Dr. T. Ishihara. 


\section{SOME StRATEgIC REFERENCES}

Brown, W. L., Jr. 1950, The status of two common North American carpenter ants. Ent. News, Philadelphia, 61: 157-161.

Creighton, W. S., 1950, The ants of North America. Bull. Mus. Comp. Zool., Harvard Univ., 104 : cf. pp. 363-370.

Emery, C., 1908, Beiträge zur Monographie der Formiciden des paläarktischen Faunengebietes: Camponotus. Deutsche Ent. Zeitschr., pp. 182-186.

Emery, C., 1925, Genera Insectorum: Formicidae, Formicinae. Fasc. 183, pp. 71-74. Menozzi, C., 1922, [On European Camponotus]. Bull. Soc. Ent. Ital, 54: 140-146. 